\title{
IMPROVING STUDENTS' VOCABULARY ACHIEVEMENT BY USING REALIA
}

*Mery Meilza Indria Aritonang

** Johan Sinulingga

\begin{abstract}
This study attempted to improve students' achievement in vocabulary by using Realia. This study was conducted by using classroom action research. The subject of the research was class VII-1 at SMP.N.17 Medan which consisted of 38 students. The research was conducted in two cycles, cycle I consisted of three meetings and cycle II consisted of three meetings. The instrument for collecting quantitative data was a vocabulary test and the instruments for collecting qualitative data included diary notes, observation sheets, questionnaire sheets, and interview. Based on the vocabulary test, students' score kept improving in every test and based on the diary notes, observation sheets, questionnaire sheets, and interview report, it was found that the teaching-learning process ran well. Students were active, enthusiastic, and interested in vocabulary. The result of the research showed that Realia significantly improved students' achievement in vocabulary.
\end{abstract}

Key Words: Vocabulary, Realia, Diary Notes, Observation, Questionnaire, Interview.

* A graduate of English Language and Literature Department of UNIMED

** A lecturer of English Language and Literature Department of UNIMED 


\section{INTRODUCTION}

\section{Background of Study}

According to introductory textbooks quoted by Brown (2000:5), language is a system of arbitrary conventionalized vocal, written, or gestural symbols that enable members of a given community to communicate intelligibly with one another. English language is the most important one in the world. It is not only as an international communication means but also to access the science and technology. In Indonesia, English is very important for students of all levels to master in order to be able to communicate with other people from foreign countries.

In terms of English teaching, one of the language aspects taught is vocabulary. Vocabulary itself is the set of words within a language that are familiar to that person (http://en.wikipedia.org/wiki/vocabulary) . Teaching vocabulary is one of the basic elements in achieving the basic skills. By mastering less vocabulary, the students will be difficult to transfer their idea in English.

There are some factors causing them feel difficult to learn English. Based on the writer's experience during the teaching practice (PPL), most of the students were not interested in English because of their lacking of vocabulary. Therefore the students could not express their English in communication skills. Thus the students always should be encouraged to study more, so that they will be able to communicate fluency by the mastery of more vocabulary. In other words, the more the students master the vocabulary the better understanding the students will be in English communication skills.

From the previous observation, the writer could say that most of students faced many problems in mastering English words. The problems are (1) getting less motivation to study English, (2) the usual teaching method was in appropriate one, the class become monotonous, (3) no reinforcement, so the students got bored, (4) teaching material merely focus on the student handbook, and (5) no teaching media was relevant. 
The problem now is how to teach English and what to teach?. Realia are objects from real life used in classroom instruction by educators to improve students' understanding of other cultures and real life situations (http://en.wikipedia.org/wiki/Realia(education)). Realia breathes life into new vocabulary, and the chances of your students remembering the new words you have taught them increases (http://EzineArticles.com/? expert=Chris_Soames). Realia has some of advantages in teaching vocabulary. Realia breathes life into new vocabulary, the chances of the students remembering new words that have thought will increase and the using of Realia helps to make English lesson memorable by creating a link between the objects and the word they represent. Besides that, using Realia stimulates the mind, bring vocabulary to life like no other visual aid and one way of encouraging creativity by involving the senses. Students can touch it, smell it, and maybe even taste it.

\section{Research Questions}

In relation to the background of the study, the research problem is formulated as follows: "Is the students' vocabulary achievement in class VII-1 SMP.N.17 Medan improved if they are taught by using Realia?"

\section{Objective of the Study}

The objective of the study is to find out whether the using of Realia is significantly improved students' vocabulary achievement in class VII-1 SMP.N.17 Medan.

\section{Significance of the Study}

The findings of research are expected to be useful: a. For the English teachers, they will understand that there is new method in teaching vocabulary that can make the teaching and learning process can be implemented fluently and well delighting. c. For the student, the students will be motivated and enthusiastic in learning English especially in learning vocabulary by using Realia. .For the readers, it will be a source of material in conducting 
the similar studies and it can enrich and expand the knowledge especially about the teaching of vocabulary by using Realia.

\section{Conceptual Framework}

\section{The Nature of Vocabulary}

Oxford Dictionary Learner's Dictionary (1987:959) defines vocabulary as: (1) the total numbers of words which (with rules for combining them) make up a language, (2) range of words known to or used by a person in a trade, profession and (3) book containing a list of words used in a book and usually written with definition or translation. Vocabulary is commonly defines as "all the words known and used by a particular person" ( http://en.wikipedia.org/wiki/Vocabulary ).

Vocabulary is one of the components of language and that no language exists without words. Words are the sign or symbols for idea. The more words we learn the more ideas we should have, so we can communicate the ideas more effectively.

According to Wikipedia on its web (http://en.wikipedia.org/wiki/Vocabulary), there are four types of vocabulary: a. Reading vocabulary; A literate person's reading vocabulary is all the words he or she can recognize when reading. b. Listening vocabulary; a person's listening vocabulary is all the words he or she can recognize when listening to speech. This vocabulary is aided in size by context and tone of voice. c. Writing vocabulary; a person's writing vocabulary is all the words he or she can employ in writing. Contrary to the previous two vocabulary types, the writing vocabulary is stimulated by its user. $d$. Speaking vocabulary; a person's speaking vocabulary is all the words he or she can use in speech. Due to the spontaneous nature of the speaking vocabulary, words are often misused. This misuse-though slight and unintentional-may be compensated by facial expressions, tone of voice, or hand gestures.

Vocabulary Achievement 
The word achievement is derived from "achieve". Based on the Oxford Advanced Learner's Dictionary, “achieve” means 1) to succeed in reaching the particular goal, status or standard, especially by effort, skill, courage, etc. 2) to succeed in doing something or causing to happen, while "achievement" means 1) a thing done successfully especially with effort and skill, 2) the act or process of achieving something. Vocabulary is a total number of words that makes up language.

To improve student's vocabulary the teacher needs to help the students. The teacher should make some correction and feedback for the shake of student's progress. Besides, the use of good and suitable methods and strategies are truly encouraged the students to improve their vocabulary.

\section{The Nature of Media}

Media are tools that teacher uses in teaching and learning process. Media can make the student to be interested in learning. The media can help the student to express their idea. According to James (http://zvavanhu.mywapblog.com/types-of-media-used-in-teachingand-lear.xhtml), Media are any devices that assist to transmit to a learner facts, skill, attitudes, knowledge and appreciation or additional materials used when using a particular teaching method to make learning easy, as it intend to help both the teacher to teach more reflectively and the learner to grasp the concepts more effectively.

According to James Wilson (1977:1), media is the resources for learning that you and your students use can influence the effectiveness of your instructional program. Creative uses of a variety of media will increase the probability that your students will learn more, retain better what they learn, and improve their performance of the skills they are expected to develop. Teaching by using media will attract more students so that they can motivate learning. The teaching materials will be clearer so that the student easy to understood and achieve the objectives of teaching. Besides that, the method will be more varied not monotonous, so the students are not bored. 


\section{Realia}

Adrienne and Jordan (2000:23) state that Realia is a term for real things-concrete object-that are used in the classroom to build background knowledge and vocabulary. Realia is used to provide experiences to build and to provide students opportunities to use all senses in learning. Realia allows the student to see, feel, hear, and even smell the object.

Richard (1992) quoted by Bryan Smith (http://iteslj.org/Articles/SmithRealia.html?ref=Guzels.TV), Realia is actual objects and items which are brought into a classroom as examples or as aids to be talked or written about and used in teaching.

According to Wikipedia (http://en.wikipedia.org/wiki/Realia_(education)) Realia are objects from real life used in classroom instruction by educators to improve students' understanding of other cultures and real life situations.

Realia is everyday, authentic objects, such as photographs, menus, brochures, receipts, maps, movies, television shows, commercials, etc. that are used to teach and learn languages. Using Realia helps students to make English lessons memorable by creating a link between the objects and the word or phrase they represent. Realia breathes life into new vocabulary, the chances of the students remembering the new words have thought

those increases. Realia stimulates the mind, and is one way of encouraging creativity by involving the senses. Using Realia will generate interest and help create an atmosphere conductive to learning.

\section{Characterization of Realia}

There are five characterization of Realia which are used by teachers in the classroom according to Douglas (2000). They are: 1) Non-repetitive: Realia exercises do not repetition for their value. In fact any particular activity of this type is often just done once, or possibly twice. This is not just because their value does not lie in repetition, but also because by their very nature they are time-consuming activities.2) Meaningful Realia has been developed in the expectation that the situation will engage the students; the result 
should be discussion that is lively and even earnest. The object which told by the students are meaningful and directed to point of the topic. The students do not just speak and write what they think in their mind, but know what is the word must say and write structurally.3) Whole practice Realia concentrate on small segments of behavior. The students do practices to improve their vocabulary. They must learn and have behavior to study more all about the objects.4) Direct At this stage; the students make efforts to practice the terminal behavior itself-actually, using language in stimulations of real situations. Stimulation is important in this respect. When the students in the class, directly they will be stimulated and tell about the object of Realia 5) Free' In Realia practice, the students are allowed to express their ideas, thoughts, feelings, in line with their wishes and capabilities. The teacher's role is not to insist that any particular language item is used. The students are free to express what they think in their mind meaningfully, like they want to say or write about the color, model, taste, etc.

\section{The steps of implementing Realia}

The steps in implementing of Realia according to Adrienne and Jordan (2000:23) are: 1) Identifying Opportunities to Use Realia: Be aware of opportunities to include Realia in lessons as you plan reread any stories to be read aloud or used for reading instruction to identify vocabulary that may be unfamiliar to the students and locate Realia that will be helpful to their understanding. The students try to find the words are difficult based on the object. For example, they have note of the difficult vocabulary and to find its meaning.2) Collecting Realia: Begin to collect items that can be stored in the classroom and organize them so that they can be easily accessed for instruction. The students try to find the objects which are used in the class. They know all of things about the objects.3) Building a Library of Realia After knowing all of things about the objects, the students have many vocabularies. For example is fruit. They know what are the English of warna (color), bentuk (model), batang (stem), and daun (leaf). They do not know before, but after learning using realia they like building a library of realia by themselves.4) Using Field Trips as Realia: If it is too large to move and the students' learning would benefit by experiencing it, take a field trip. Give students the opportunity to really understand what they are studying. 
The students will be more spirit after see the object directly. But for note here, if it is the object impossible brought into the class like building of school, Borobudur temple, etc. the writer can bring and show the photograph of it because photograph is one kind of Realia.

Realia in learning vocabulary is a real media to creating a link between words and real world. Realia has some of the advantages in teaching learning English especially in teaching vocabulary. Realia breathes life into new vocabulary, the chances of the students remembering the new words have thought those increases. Realia stimulates the mind, and is one way of encouraging creativity by involving the senses. By using Realia, the students will be more interested to study, the word will be memorable for the students.

\section{METHODOLOGY}

\section{Research Design}

This research was based on Classroom Action Research. According to Wallace (1998:1), action research is defined as the systematic collection and analysis of data relating to the improvement of some aspect of professional practice. The purposes of action research were to improve the quality of studying practice, to find solution and to solve the problem. There were four phases each of cycle, namely: 1) planning, 2) action, 3) observation, and 4) reflection. Actually, if the result failed, it would be continued to next cycle by renewing the previous steps to solve the problem. The new cycle would improve of teaching decision. If the new planning increased students' vocabulary skill, the cycle would stop. If it did not increase students' skill, cycle would continue on and on the next cycle until result determined was research.

\section{Subject}

The subject of this research was the first year students of SMP.N.17 Medan. The subject of the research was one class which consisted of 40 students. The reason for choosing this class was because the writer assumed that those students in the class would show the significant improvement in their vocabulary. The writer had chosen VII-1 class. 


\section{Data Collection}

In collecting data, the data was collected by using quantitative and qualitative data. In collecting quantitative data, the writer used vocabulary test as the instrument to measure their ability in vocabulary. The test was given to the students by listing the vocabulary based of the Realia. The data was collected by using vocabulary test to the student that consists of 20 multiple choice items based on the topic from the textbook. It was analyzed the students' learning level.

The quantitative data was diary notes, interview sheet, questionnaire sheet, and observation sheet. The writer used diary notes to write the result of the observation. Diary notes contained the writers' personal evaluation about the class and the progress of the project.

Interview sheet was useful to get information about the project which was done in two cycles both students and teacher. The writer was interviewed the students to know their weakness and their problems in learning. Also the writer was interviewed the teacher to know her ways in teaching vocabulary. Questionnaire sheet was necessary to identify what is happening in teaching learning process. Observation was useful to know students' reaction and to see the development that is exist since applying Realia media.

\section{Research Procedure}

The procedure of data collection was conducted by implementing two cycles and three meetings of each cycle. These included four steps namely: planning, action, observation, and reflection.

Before the procedure of data collection was begun, the writer administered to identify the Basic knowledge about the students' vocabulary achievement.

\section{Cycle I}


In the cycle 1, the students' vocabulary achievement was measured and their problems in vocabulary were analyzed. The students' attitudes toward vocabulary were seen.

\section{Planning}

Planning was done to arrange everything that was needed in action. The arrangements included: 1).Got pre test score that was used to know the students' basic knowledge in vocabulary before doing cycle 12 2).Prepared lesson plan 3).Prepared and designed the vocabulary material that was used as long as the cycles which referred to the textbook that used or other relevant textbook 4).Prepared the interview, questionnaire and observation sheet that was used to know students' reaction and class condition as a whole, and also to see the development that existed since applying vocabulary achievement by using Realia 5).Determined the collaborator who was helped the researcher to do the research to analyze the weakness in learning process and to reflect the result of teaching learning process 6).Planned and designed the application model of teaching learning scenario of Realia 7).Prepared the assignment need.

\section{Action}

Action meant the process of activity that was done. Action was the implementation of planning. On the other hand, action was guided by planning that had been made formerly. In action, the teacher taught the students how to improve their vocabulary by using Realia. In this case, teacher applied the plan that had been arranged and used Realia in teaching vocabulary. At the end of action, vocabulary evaluation was administered in order to measure students' vocabulary achievement.

The activities that was done in action as follows:

Table 3.1 Scenario of Teaching

\begin{tabular}{|l|l|}
\hline Activities & Output \\
\hline
\end{tabular}




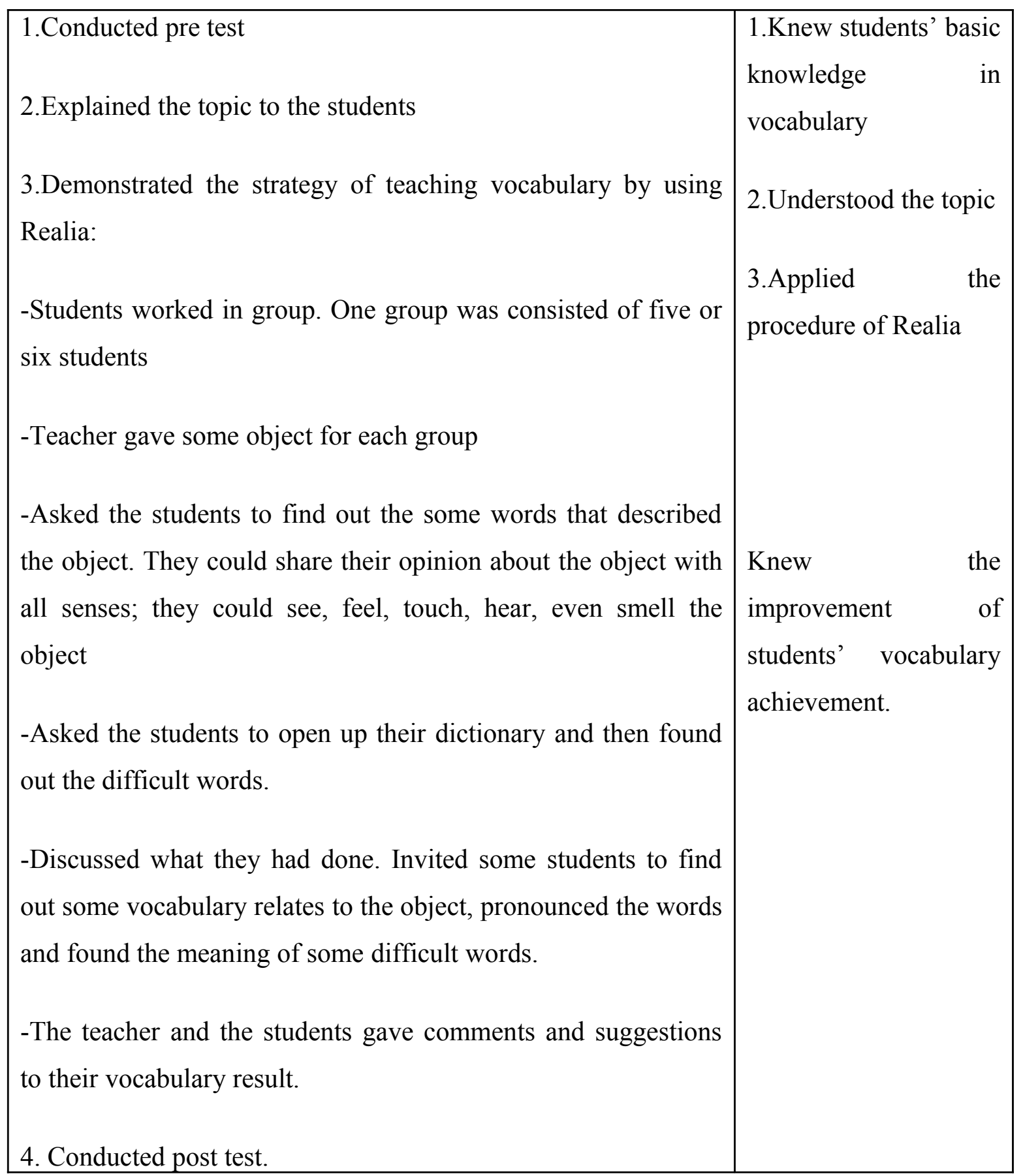

\section{Observation}

Observation aimed at finding out the information to be evaluated and was the basic of reflection. In this case, the collaborator observed all the situations or conditions that happened during the process of teaching and learning, the attitudes of the students while 
doing their work in groups, the contribution of all students in their group whether they are active or not, and their attitudes in doing the writing evaluation. The result of observation was noted in observation sheet. Questionnaire was also used to know some factors that happened out of class that affected students' vocabulary achievement. Students answered some questions related to their feeling, problem and other condition out of class. It was necessary to know how great effect of these things on students' vocabulary achievement.

\section{Reflection}

Reflection was the evaluation or feedback process of the action that had been done. It was very necessary to help the writer to make decision for what done or revised. From the result of the observation, the problem that existed, the causes of the problem was analyzed.

\section{Cycle II}

Based on the result of the result I, the writer decided to do the cycle II in learning process. From the evaluation in cycle I, it was found that the students score was still low. The writer made the planning based on the difficulties of students to improve their achievement in vocabulary.

In observation, the collaborator assisted the writer in conducting the action research; the collaborator observed the students' activity during teaching learning process. The result of cycle II was expected to get better than the result of cycle I. Besides that, the cycle I was connected and continued to the cycle II to know and determine the students' value in the cycle I was true.

\section{Validity and Reliability}


A test with high content validity gained by (1). Identifying the subject-matter topics and behavioral outcomes to be measured, (2). Building a table of specification which specifies the sample of item to be used, and (3). Constructing a test that closely fits the table specification.

Reliability refers to the consistency of test scores that was; to how consistent they were from one measurement to another. Reliability refers to whether or not a measuring technique was consistent. Reliability was a concern with how consistently we were measuring whatever we were measuring. Therefore, if the score of students were consistent, the test was considered reliable. The simplest means of estimating the reliability of test scores from one single administration of a test is by using Kuder-Richardson Formula-21. It was used because this study uses the objective test.

\section{Scoring of Vocabulary}

The test was multiple choice tests. There were about twenty questions for each cycle. In scoring the vocabulary test, it was determined that the ranging from $0-100$ by accounting the correct answer.

\section{The Technique of Data Analysis}

This research used qualitative and quantitative data. The qualitative data was used to describe the situation during the teaching process and the quantitative data was used to the score of the students. The qualitative data analyzed from the diary notes, observation sheet, questionnaire sheet and interview. The qualitative data was analyzed by computing the score of vocabulary test.

\section{RESULTS AND DISCUSSION}


Based on the results of quantitative and qualitative data, it was found that the application of Realia had successfully improved students' achievement in vocabulary. In the first meeting, the students' were given the writing test I (pre-test). From the test I, it was found that students' achievement was still low in vocabulary. They were lack of vocabulary, they felt difficult to remember the words, and they were bored to memorize vocabulary. Next, the first cycle of classroom action research was conducted and Realia was applied at the first time. Although they still had problem, the result of cycle one was better than that of vocabulary test I and after the writer conducted the second cycle, the result was better than that the first cycle. In another words, based on the quantitative data, the students' vocabulary became better in every vocabulary test. It indicated that the application of Realia was effective because it improved students' achievement in vocabulary.

The qualitative data taken from diary notes, observation sheet, questionnaire sheet, and interview report showed that the students gave their good attitudes and responses during the teaching and learning process. Even though they got problem at the first time but they could handle their difficulties and enjoyed their lesson by the process of time. They became more active and interested in vocabulary. The questionnaire and interview report showed that students strongly agree that the implementation of Realia helped them in vocabulary. These all qualitative data supported the research findings which based on the quantitative data.

Realia is actual objects and items which are brought into a classroom as examples or as aids to be talked or written about and used in teaching. Realia is a term for real thingsconcrete object used in the classroom to build background knowledge and vocabulary. Realia is used to provide experiences on which to build and to provide students opportunities to use all senses in learning. Realia allows the student to see, feel, hear, and even smell the object. Realia breathes life into new vocabulary, the chances of the students remembering the new words have thought those increases. 
The improvement of students' vocabulary can be seen from the result of the analysis of qualitative and quantitative data. It means that the students' achievement in vocabulary by using Realia improved.

\section{CONCLUSION AND SUGGESTIONS}

\section{Conclusion}

Based on the result of data analysis the mean scores of students in cycle II is significantly higher than that of the scores in cycle I. It can be said that there is a significant improvement on the students' achievement in vocabulary by using Realia. It can be seen from the improvement of mean of students' score, namely: the mean of the vocabulary test I $(61,72)$ increased to the mean of the vocabulary test II in cycle I $(81,85)$ and to the vocabulary test III in cycle II $(92,90)$. The score continuously improved from the vocabulary test I to the vocabulary test III in cycle II. Diary notes and observation results showed that the students gave their good attitudes and responses during teaching and learning process by using Realia. Questionnaire and interview report showed that strongly agree that the implementation of Realia had helped them in vocabulary. So, it can be concluded that the application of Realia significantly improved students' achievement in vocabulary in Class VII-1 SMP NEGERI 17 Medan.

\section{Suggestion}

The study showed that the application of Realia could improve students' achievement in vocabulary based on which some points are suggested, as follow: a. for The English teachers are suggested to use Realia in teaching vocabulary because this media helps the teachers to develop their vocabulary, and build the students' motivation to study b.for the readers who are interested for further study (university students) related to this research should explore the knowledge to enlarge their understanding about how to improve vocabulary and search another reference. 


\section{REFERENCES}

Amberoid, J.A., \& Field, M.L. 1997. From Reader to Reading Teacher. Cambridge: Cambridge University Press. 
Brown, J.W. 1977. AV Instruction Technology, Media and Methods (6th Ed.). USA: McGraw-Hill.

Brown, H.D. 2000. Principles of Language Learning and Teaching (4th Ed.). San Fransisco: Addison Wesley Longman.

Expert. (Anonymous, n.d.) http://EzineArticles.com/?expert=Chris Soames. Retrieved June 23, 2011.

Gerlach, V.S., \& Donald P.E. 1980. Teaching and Media a Systematic Approach (2nd Ed.). New Jersey: Prentice-Hall.

Harrell, A., \& Jordan, M. 2004. Fifty Strategies for Teaching English Language Learners (2nd Ed.). New Jersey: Pearson Education.

Hornby, A.S. 2000. Oxford Advanced Learner's Dictionary. UK: Oxford University Press.

Measurement. (Anonymous, n.d.) http://www.Adprima.com/measurement.htm. Retrieved July 31, 2011.

Realia. (Anonymous, n.d.) http://en.wikipedia.org/wiki/Realia(education). Retrieved July 31, 2011.

Smith, B. Virtual Realia. (n.d.). http://iteslj.org/Articles/Smith-Realia.html?ref=Guzels.TV. Retrieved June 23, 2011.

Types of Media. (Anonymous, n.d.). http://zvavanhu.mywapblog.com/types-of-media-usedin-teaching-and-lear.xhtml. Retrieved July 31, 2011.

Vocabulary. (Anonymous, n.d). http://en.wikipedia.org/wiki/vocabulary. Retrieved July 31, 2011. 
Vocabulary Assessment. (Anonymous, n.d.). http://math-and-reading-help-forkids.org/vocabulary assessment.html. Retrieved July 31, 2011.

Wallace, M.J. 1998. Action Research for Language Teachers. Cambridge: Cambridge University Press. 